\title{
POPULATION STUDIES OF THE EUROPEAN SPRUCE SAWFLY \\ (Gilpinia hercyniae Htg.) \\ IN QUEBEC
}

\author{
By R. Martineau, F.E., M.Sc. \\ Entomological Service, Dept. of Lands and Forests, 2uebec.

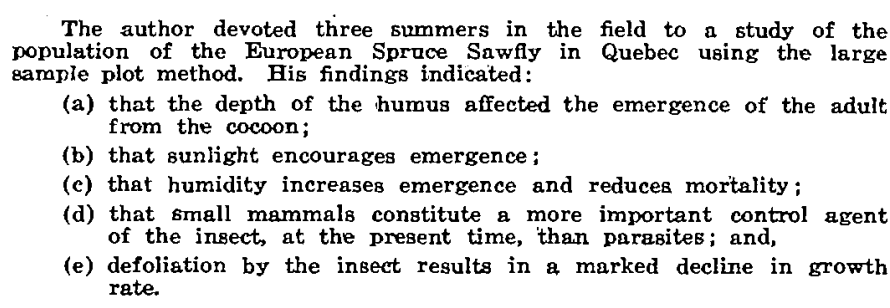

\section{INTRODUCTION}

$\mathrm{T}$

HE large sample plot as a method of investigating animal populations living in the ground has been employed mainly by zoologists working with small vertebrates that complete their life histories within restricted areas. In entomology, the investigations carried out by Iljinski (1936) on the larval population of Dendrolinus pini $\mathrm{L}$. seem to be the only case in which the large sample plot was used as a method of ground sampling. He first chose a typical area within which the trees were connected by strips one half meter wide. These strips, varying in length from one to 26 meters, were then subdivided into one-meter units and the insects were collected within the subdivisions. Three test plots containing 63 strips laid out between 61 trees were examined. It can be seen that the area was rather large as compared with the square foot or the square meter sample areas used by most of the soil investigators.

Although Iljinski's method seems quite appropriate for population studies, very few entomologists have employed it in the analysis of insect populations, probably on account of the great number of workers required. The Quebec Entomological Service had an opportunity to use this method three years ago, when a project involving the collection of European spruce sawfly cocoons (Gilpinia hercyniae Htg.) for parasite breeding was initiated in the Gaspe Peninsula. A series of ecological studies was made at the same time to determine the influence of environment on this sawfly in the cocoon. Ad vantage was taken of such large sample units also to check various small sampling methods, which will be treated in detail in a forthcoming paper.

The work was started on the south side of Lake Ste. Anne, Gaspe Peninsula, in July, 1938. In two months, approximately 380,000 cocoons were

(1) Contribution No. 19. Entomological Service, Dept. Lands and Forests, Quebec, Canada. This paper was submitted in partial fulfilment of the requirements for the Degree of
Master of Science in Entomology in the Graduate School of The University of Illinoig. 
collected and two sample plots each of 2,500 square feet were investigated. During the two following summer seasons the work was continued in the Matapedia Valley region which was also infested by the insect. In 1939, $1,600,000$ cocoons were serit to the Dominion Laboratory at Belleville for parasite rearing, and a total of 3,270 square feet of surface humus was studied at Ruisseau Creux and Albertville. The summer of 1940 was spent at Ste. Florence where the collection came up to 2,000,000 cocoons and where the quantitative studies covered an area of 1,800 square feet.

The writer wishes to express his appreciation to the National Forestry Program, which furnished the crews of men necessary for the execution of the work in the forest during two summer seasons; to Dr. A. R. Gobeil, former Director of the Quebec Forest Entomological Service, both for the suggestion of the work and his advice in the organization and design of the field work; and to Prof. W. V. Balduf of the Department of Entomology, University of Illinois, for his many helpful suggestions in the analysis of the data and preparation of the manuscript.

\section{Procedure}

\section{Location}

Establishment of the Plot

Since the project involved quantitative studies and thus necessitated large numbers of individuals, the abundance of the sawly was the principal factor in determining the selection of the region. For this reason the Gaspe Peninsula seemed an ideal place to undertake the work. In fact, that region was the only place in Quebec, except for scattered stands west of the Matapedia, where mortality had been caused by the spruce sawfly (Balch, 1939). The two types of stands studied in this region were black spruce and mixed spruce.

Because the spruce sawfly shows a preference for white spruce, it was found important to include white spruce stands in our study. For this reason the Matapedia Valley region, southwest of the Gaspe Peninsula and adjacent to it, was chosen for the second year of the project. Dead trees were not as numerous as in the Gaspe region, yet in many stands there had been some mortality. A study of black spruce type was first repeated at Ruisseau Creux in 1939, and the white spruce type was investigated at Albertville the same year and at Ste. Florence in 1940.

Within the limits of these stands, due attention was given to the choice of the plot so that it could be located on an area typical of the local infestation. This was done by making a general survey across the forest stand previous to the establishment of the plot.

\section{Delineation}

The size of the plot was dependent upon the number of men and the amount of time available, but the nature of the stand was also a factor of great importance. As far as possible the plots were made rectangular and their boundaries marked by strings stretched between corner posts. Data were also taken on an area 10 feet wide surrounding the plot to furnish further details upon the nature of the habitat. 
To estimate the proportion of the area covered by each species of plants and to obtain information on the effects of such factors as depth of humus and ground cover, the plots were divided into subplots. These were at first irregular in form, so as to include in each of them only trees of one species. But as some doubts were expressed later concerning the desirability of this irregular type the last sample plots investigated in 1940 were divided into subplots of uniform size and shape with no regard to position or species of trees. A map was prepared for each plot showing boundary lines, subplot divisions, position of trees and in some cases crown projections.

\section{General observations}

\section{(a) Topographical notes}

The first essential requirement consisted in determining the location of the plot. Notes were also taken on the altitude, the slope, the exposure of the area studied, and on all important ecological facts concerning the surroundings.

\section{(b) Botanical notes}

The depth of the humus layer was first determined. The method consisted in forcing a measuring stick through the litter down to mineral soil. Many tests were made in each subplot, the number depending upon its size, and the mean of these measurements was recorded.

Each plant was identified to genus when not to species and its abundance had to be recorded separately for each subplot. Four main divisions were made, namely, mosses, herbaceous plants, seedlings and trees. The abundance of the mosses was obtained by estimating the percentage of area covered by each species, the presence of only one or two individuals being indicateo by the sign + . The estimation of the abundance of herbaceous plants involved the use of a standard established as follows: "very abundant", "abundant", "rare" and "very rare". The seedlings usually known as constituting the reproduction were individually counted.

Studies on trees necessitated more intensive work. The diameters at breast height (D.B.H.) were taken with a pair of calipers, and the heights of the trees and of the crowns with a hypsometer. The crown radius was also taken in plots II, IV and V in order that the crown projections might be drawn on the map. Growth studies were made with an increment borer.

\section{(c) Entomological notes}

The entomological data fall under three main headings: defoliation, larval population and cocoon population. It is well known that the European spruce sawfly shows preference for the old foliage (Balch, 1939). Accordingly the approximate percentage of defoliation for the old and new foliage was registered separately. These observations were generally made at the end of the summer. Defoliation was first estimated in classes of 10 per cent but it was found later that for practical purposes and the sake of clearness the four following classes would be sufficient (Gobeil, 1940): light $(0.25 \%)$, moderate $(25.50 \%)$, medium $(50.75 \%)$, heavy $(75-100 \%)$. 
The larval population was obtained by the well known method of spread. ing a canvas beneath the tree, then jarring the tree vigorously with an axe and counting the larvae. This method, however, had a very great disadvantage in our case, due to the fact that small trees which could be jarred effectively were not always easy of access. Consequently the data obtained were not always representative of the true population.

The most important phase of our work was the study of the cocoon population in the soil. All the cocoons were collected from the litter down to mineral soil in the entire sample plot and the population recorded (Fig. I). Ten per cent of the area was checked and the correction factor thus obtained was applied to the entire population.

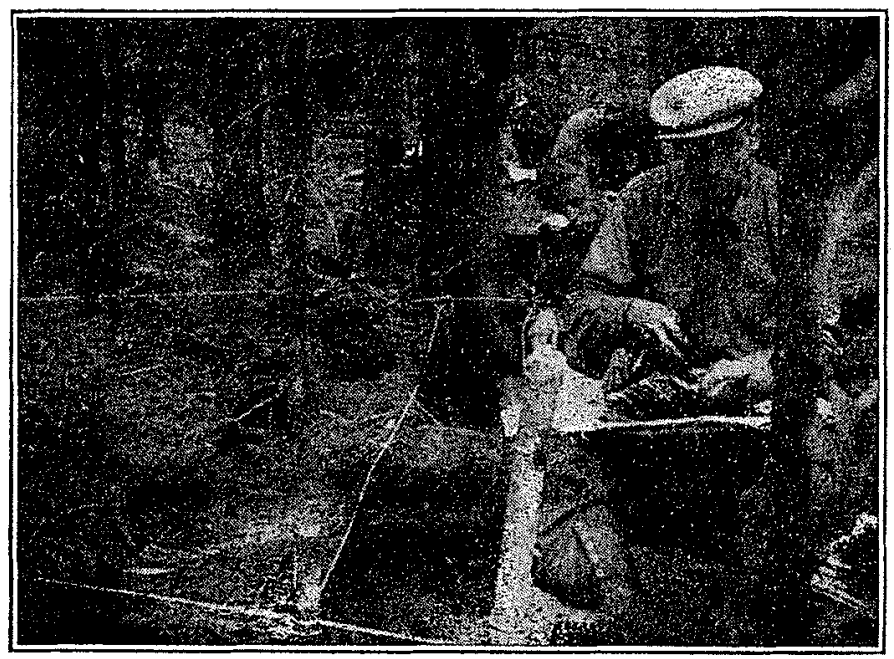

Fig. I. Men looking for cocoons in the humus.

To be able to compare our data, the sampling was made in the same months every year. After collection, all the cocoons were carefully ex. amined by experienced men for classification into one of the five following groups: (1) "sound", i.e. cocoons containing living insects; (2) "dead"; (3) "chewed"; (4) "emerged", identified by a smooth circular opening through which the sawfly issued; and (5) "parasitized", which were characterized by a relatively small hole in the cocoon.

\section{Description of the Plots ${ }^{1}$}

Plot I.-Mature black spruce stand. We started our studies in the Gaspe region in a softwood stand on the south side of Lake Ste. Anne at 1,350 feet above sea-level. Most of this territory is in coniferous forest except the highest peaks of the Allegheny mountains which are in tundra. The vege. tation is typical of moist habitats. A careful examination of the tree crowns revealed a defoliation of 100 per cent on the old foliage and 70 per cent of the current growth.

\footnotetext{
1. See Table 1.
} 
Plot II.- Young black spruce stand. A second plot was established in a black spruce stand along Ruisseau Creux in the Matapedia Valley where climatic conditions are less severe than in the Gaspe region. The area consists mainly of large table-lands, characterized by steep slopes gullied by streams or rivers. The steeper slopes are covered with pure black spruce stands, but, in general, black spruce is associated with white spruce and balsam fir, stands recently damaged by fire. We also found isolated white birch stands.

Plot III.-White spruce pasture stand. This young pasture stand was characterized by a thin layer of humus and a scanty herbaceous growth, showing that a few years ago the same area was under cultivation. This plot was also located in Matapedia county, Matalic township, and climatic conditions were quite similar to those of Ruisseau Creux. The topography was also quite similar although the slopes were less abrupt. A tremendous number of larvae were found per tree and the number of cocoons per square foot was the highest found for all the plots. The percentage of sound cocoons was also much higher in this plot than in any other.

Plots IV and V.- Young white spruce stands. Two other stands of white spruce were studied on lot 2, Milnikek township in Matapedia county. The two stands differed only in density, Plot V being more open. Although located in the vicinity of cultivated land, both plots were part of a large forest area presenting the same topography and climate as described for Plot III. The average cocoon population per square foot was much higher in all the white spruce stands than in the others.

Plot VI.-Mixed type. The last type to be studied was a mixed spruce stand located in the vicinity of Plot I. Its altitude was about 300 feet higher than Plot I, and the remarks given for same on topography and climate apply to Plot VI as well. Defoliation was very pronounced although only 37 cocoons were found per square foot. This is due to the fact that only 35 per cent of the trees were spruce.

\section{Factors Affecting the Population}

The determination of the influence of various environmental factors affecting the population of the spruce sawfly was arrived at by comparing the entomological data obtained for the various habitats studied. The percentages of emergence and mortality used for comparison were calculated by the following formulae:

$$
\begin{array}{ll}
\text { Percentage of emergence }= & \frac{100 \times \text { (emerged cocoons) }}{\text { sound }+ \text { emerged cocoons. }} \\
\text { Percentage of mortality }= & \frac{100 \times(\text { dead cocoons })}{\text { dead }+ \text { sound }+ \text { emerged coconon }}
\end{array}
$$

The other percentages were calculated out of the whole population. Per. centages thus obtained cannot be considered as representing the emergence or mortality of a particular year because they are based on cocoons accumu- 
Table 1. Summary of the Generac

\begin{tabular}{|c|c|c|c|c|c|c|c|}
\hline & & & & \begin{tabular}{c|} 
Lit- \\
ter
\end{tabular} & $\begin{array}{l}\text { Herb \& Shrub } \\
\text { Stratum }\end{array}$ & \multicolumn{2}{|c|}{ Tree } \\
\hline 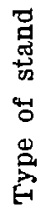 & 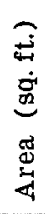 & 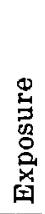 & $\begin{array}{l}\stackrel{\Phi}{O} \\
\stackrel{0}{\sigma}\end{array}$ & 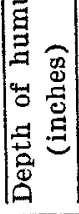 & 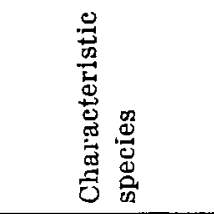 & 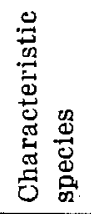 & 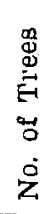 \\
\hline
\end{tabular}

I. Black spruce

A. Mature stand. 2500 North

156.6 Sphagnum,

Hylocomium splendens Balsam fir

Black spruce 53

Calliergon schreberi

Vaccinium vitisidaea

Picea mariana

Abies balsamea

B. Young stand . 2250 West $30 \quad 2.5$ Calliergon schreberi Hypnum crista

Black spruce

Balsam fir castrensis

Picea mariana

Abies balsamea

II. White spruce

Calliergon schreberi

White spruce

Red spruce

Picea canadensis

Balsam fir

23

A. Pasture stand

1020 North 7

Abies balsamea

B. Young dense

900 East

56

6.3 Calliergon schreberi

Mitella nuda

Rubus flagellaris

White spruce

Abies balsamea

Pyrus communis

C. Young open stand ....... 900 East

$5 \quad 4.5$ Calliergon schreberi

Cornus canadensis

Aralia nudicaulis

Black spruce

17

Pyrus communis

White spruce

Black spruce

7

III. Mixed type ..

2500 North

5

Hylocomium

splendens

Oxalis acetosella

Cornus canadensis

Picea mariana

Abies balsamea

Balsam fir

White spruce

Black spruce

White birch

37
14
7
2 
Conditions Obşgrved In EAch PIot

\begin{tabular}{|c|c|c|c|c|c|c|c|c|c|c|c|}
\hline \multirow[b]{2}{*}{$\begin{array}{l}0 \\
0 \\
0 \\
0\end{array}$} & \multicolumn{5}{|c|}{ Stratum } & \multicolumn{6}{|c|}{ Cocoon Population } \\
\hline & 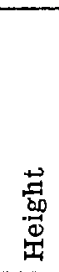 & $\stackrel{8}{80}$ & 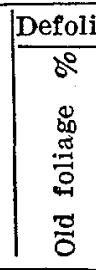 & 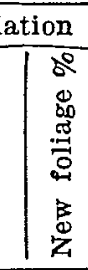 & 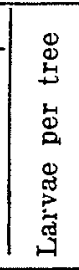 & 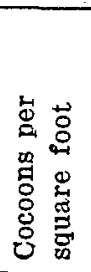 & 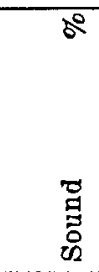 & 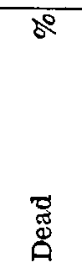 & $\begin{array}{l}80 \\
0 \\
0 \\
0 \\
0 \\
0 \\
0\end{array}$ & $\begin{array}{l}50 \\
80 \\
0 \\
000 \\
0 \\
0 \\
0 \\
01\end{array}$ & 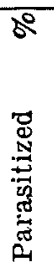 \\
\hline $\begin{array}{l}5.0 \\
3.5\end{array}$ & $\begin{array}{l}36 \\
18\end{array}$ & 120 & 100 & 70 & 57 & 55 & 9.0 & 2.9 & 65.9 & 21.4 & 0.8 \\
\hline $\begin{array}{l}6.2 \\
6.5\end{array}$ & $\begin{array}{l}29 \\
32\end{array}$ & $\begin{array}{l}61 \\
46\end{array}$ & $\frac{80}{-}$ & $\underline{30}$ & - & 60 & 4.3 & 3.4 & 82.2 & 9.9 & 0.2 \\
\hline $\begin{array}{l}4.5 \\
3.0 \\
3.0\end{array}$ & $\begin{array}{l}23 \\
25 \\
-\end{array}$ & $\begin{array}{l}20 \\
20 \\
-\end{array}$ & $\begin{array}{r}60 \\
0 \\
-\end{array}$ & $\begin{array}{r}50 \\
0 \\
-\end{array}$ & 1236 & 112 & 43.1 & 1.1 & 48.4 & 7.1 & 0.3 \\
\hline $\begin{array}{l}6.1 \\
5.4\end{array}$ & $\begin{array}{l}48 \\
36\end{array}$ & $\begin{array}{l}50 \\
40\end{array}$ & & $\begin{array}{l}60 \\
50\end{array}$ & - & 90 & 9.9 & 10.0 & 61.1 & 16.2 & 1.9 \\
\hline $\begin{array}{l}7.2 \\
7.7\end{array}$ & $\begin{array}{l}40 \\
52\end{array}$ & $\begin{array}{l}50 \\
50\end{array}$ & & $\begin{array}{l}60 \\
60\end{array}$ & - & 102 & 9.4 & 40.5 & 41.3 & 5.5 & 3.3 \\
\hline $\begin{array}{r}5.1 \\
5.6 \\
6.6 \\
11.0\end{array}$ & $\begin{array}{l}39 \\
46 \\
46 \\
52\end{array}$ & $\begin{array}{l}-\overline{60} \\
70 \\
-\end{array}$ & $\begin{array}{r}-100 \\
90 \\
-\end{array}$ & $\begin{array}{l}- \\
90 \\
60 \\
-\end{array}$ & 8 & 37 & 13.8 & 14.5 & 54.1 & 17.0 & 0.9 \\
\hline
\end{tabular}


lated from many years. But since it was impossible to separate the cocoons according to year and since the same formula was used in all cases, we feel that such a procedure stands good for comparison purposes.

\section{A. Efrect of Humus and Ground Cover.}

\section{Emergence}

The percentage of emergence was calculated for each of the subplots which were classified into five groups based on the depth of the humus. The data are summarized in Table 2. No record of Plots II and III appears in this table since the depth of humus was about uniform for all the subplots.

Before interpreting the data it should be stated that the influence of the depth of humus will vary according to its moisture content and emergence should probably be higher in a moist than in a dry humus. On the other hand, in the black spruce type, we often have 6 or 7 inches of Sphagnum moss and a deep layer of saturated humus where the ground temperature is lower than that of the white spruce type. In such a case emergence might be sometimes lower on account of temperature.

Table 2. addit Emergevce in Retation to the Depth of Huarus

\begin{tabular}{|c|c|c|c|c|c|c|c|c|c|}
\hline \multicolumn{10}{|c|}{ Sample Plots } \\
\hline \multirow{2}{*}{$\begin{array}{l}\text { Depth } \\
\text { of } \\
\text { humus }\end{array}$} & \multicolumn{3}{|r|}{ I } & \multicolumn{2}{|r|}{ IV } & \multicolumn{2}{|c|}{$\overline{\mathrm{V}}$} & \multicolumn{2}{|c|}{ VI } \\
\hline & & $\begin{array}{l}\% \text { of } \\
\text { emer- } \\
\text { gence }\end{array}$ & $\begin{array}{c}\text { No. of } \\
\text { sub- } \\
\text { plots }\end{array}$ & $\begin{array}{l}\% \text { of } \\
\text { emer- } \\
\text { gence }\end{array}$ & $\begin{array}{r}\text { No. of } \\
\text { sub- } \\
\text { plots }\end{array}$ & $\begin{array}{l}\text { \% of } \\
\text { emer- } \\
\text { gence }\end{array}$ & $\begin{array}{l}\text { No. of } \\
\text { sub- } \\
\text { plots }\end{array}$ & $\begin{array}{l}\text { \% of } \\
\text { emer- } \\
\text { gence }\end{array}$ & $\begin{array}{l}\text { No. of } \\
\text { sub- } \\
\text { plots }\end{array}$ \\
\hline $2^{\prime \prime}-4^{\prime \prime \prime}$ & $\ldots$ & & & 10.8 & 7 & & & 33.6 & 2 \\
\hline $4 "-6 "$ & $\ldots$ & 71.0 & 4 & 20.3 & 5 & 68.7 & 5 & 42.9 & 5 \\
\hline $6 "-8 "$ & $\ldots$ & 71.1 & 7 & & & 61.9 & 2 & 25.1 & 2 \\
\hline $8^{\prime \prime}-10^{\prime \prime}$ & $\ldots$ & 72.2 & 3 & & & 55.5 & 2 & & \\
\hline $10^{\prime \prime}+$ & $\ldots$ & 76.4 & 1 & & & & & & \\
\hline
\end{tabular}

From the data given in Table 2 we have the maximum emergence where the layer of humus reaches from 4 to 6 inches deep. In each plot except number I, the highest percentage of emergence is found in this class. Where the layer of humus is less than 4 inches, the evaporation is rapid due to a fast penetration of the sun's rays and better circulation of air. As a result the emergence is lower due probably to a lack of humidity. On the other hand where the humus layer reaches more than 6 inches in depth, even if there is enough humidity, the temperature, which has a direct bearing upon the development of insects, is probably too low to favor as high emergence as in the 4 to 6 inches class.

The data collected in the black spruce type (Plot I), however, are not in conformity with the above statements. Although in this particular case the differences between the percentages representing the various classes are not statistically significant, the following explanation might be given for this inconsistency. In this black spruce habitat the humus was so saturated and the ground temperature so low, that even in the 8 and 10 inch classes the 
conditions were almost the same as in the 4 inch class. For this reason the depth of the humus layer did not have such a characteristic influence on adult emergence as noted in the other types.

\section{Activities of mammals}

The relation of humus depth to the destruction of cocoons by rodents is best illustrated by a comparison of Plots IV (dense stand) and V (open stand) which were located on the same lot. The two white spruce stands represented by these plots were 40 years old, and were subject to the same climatic conditions, being only 200 feet apart. Moreover the population found per square foot was approximately the same, that is, 90 cocoons in the first case and 100 in the second.

The main difference was in the density of the stand and consequently in the depth of humus which was 6.2 inches deep in the dense stand and 4.5 inches in the open stand. Other conditions being more or less equal, difference in depth of humus possibly accounts for the sharp divergence (Table 3) in the action exerted by shrews upon the cocoon population of these two plots.

According to R. M. Anderson (letter of Feb. 18, 1942) the forest canopy is a favorite habitat for a number of species of shrews. From observations made by Graham (1929) on the larch sawfly, it would appear that mice are most effective in places that are not very wet and where the ground is covered with moss or loose material through which they can burrow easily. Under such conditions mice find an abundance of food and shelter throughout the year. On the other hand no tendency was noted on the part of mice to concentrate where the sawly cocoons are most abundant. According to Graham then the shelter would be the most important factor affecting activities of the rodents.

Table 3. Chewed Cocoons in Relation to the Deptir of Humeus

\begin{tabular}{cccccc|c|c|c}
\hline \hline $\begin{array}{c}\text { Plot } \\
\text { No. }\end{array}$ & $\begin{array}{c}\text { Depth } \\
\text { of humus }\end{array}$ & $\begin{array}{c}\text { Total } \\
\text { population }\end{array}$ & $\begin{array}{c}\text { Population } \\
\text { per sq. ft. }\end{array}$ & $\begin{array}{c}\text { \% of chewed } \\
\text { cocoons }\end{array}$ & $\begin{array}{c}\text { No. of } \\
\text { hoards }\end{array}$ & $\begin{array}{c}\text { Hoard } \\
\text { content }\end{array}$ & $\begin{array}{c}\text { Averago } \\
\text { per } \\
\text { hoard }\end{array}$ \\
\hline IV & 6.2 & 80,908 & 90 & 61.1 & 18 & 2,040 & 113 \\
V & 4.5 & 91,532 & 102 & 41.3 & 8 & 518 & 65 \\
\hline
\end{tabular}

It would appear from the data given above that the shrews are influenced by the depth of humus both in the choice of a location for their hoards and in their activities. A total of 18 rodent hoards were found within the limits of the first plot whereas in the second where the layer of humus was 2 inches thinner, although equivalent in area, the litter contained only 8 hoards. This relation becomes still more obvious after examination of the hoards' contents. The average population found in the first plot was 113 cocoons and in the second plot 65 cocoons.

From the above facts I am inclined to believe that the destruction of cocoons by rodents is influenced by the depth of humus. To a certain extent the rodents would prefer a deep layer of humus to build their runways. Accordingly we should normally expect a larger control by the rodents in 
old and dense forest stands since these usually have a deeper layer of litter.

\section{Activities of parasites}

No striking correlation is shown between the depth of humus and the percentage of parasitism. However, the latter is so small that it would be unwise to make any deduction from our results. For this reason the data are not tabulated.

\section{Emergence}

\section{B. EfFect of StnLight}

The relationship of adult emergence to sunlight is illustrated by an ex. periment which was made on 10 trees in 1939 and checked on 4 additional trees in 1940. This experiment was planned upon the assumption that, the surface outside the crown projection being less shaded than the area under the crown, the temperature of the soil should gradually increase with distance from the base of the tree and the emergence be higher. A strip one foot wide was laid out, regardless of the side of the tree, from the tree trunk to a point generally 2 or 3 feet beyond its crown circumference. The strip was then subdivided into one foot units and the cocoons collected within the subdivisions were recorded separately. The percentages of emergence were then calculated and the data tabulated (Table 4).

Table 4. Influence of SUnlight dpon Adolt Emergence.

\begin{tabular}{|c|c|c|c|c|c|c|c|c|c|c|}
\hline \multirow{2}{*}{ 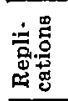 } & \multicolumn{8}{|c|}{ Percentages of emergence at various distances from the trunk } & \multirow[b]{2}{*}{ 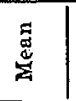 } & \multirow{2}{*}{ 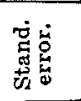 } \\
\hline & $\mathbf{1}$ & 2 & 3 & 4 & 5 & 6 & 7 & 8 & & \\
\hline 1 & 60. & 83.3 & 76.9 & 72.2 & 80.8 & 60.7 & 100. & 83.3 & 77.1 & $\overline{12.9}$ \\
\hline 2 & 33.3 & 100. & 81.8 & 81.1 & 80.8 & 91.7 & 33.3 & 0. & 63.1 & 26.6 \\
\hline 3 & 33.3 & 0. & 56.6 & 55.5 & 37.5 & 55.5 & 75.2 & $\overline{90.3}$ & 50.3 & 25.7 \\
\hline 4 & & $\overline{0 .}$ & 64.5 & 65.2 & 71.4 & 96.4 & 86.3 & 77.7 & 65.9 & 28.9 \\
\hline $\mathbf{5}$ & 33.3 & $\overline{29.4}$ & 37.5 & 43.7 & 47.1 & 66.3 & 50. & - & 43.9 & 11.4 \\
\hline 6 & 52.2 & 100. & 83.3 & 47.1 & 71.4 & 100. & 52.3 & 33.3 & 67.4 & 25.8 \\
\hline 7 & 73.3 & 70.8 & 63. & 66.6 & 100. & 66.6 & 50. & 0. & 61.3 & 28.6 \\
\hline 8 & 61.9 & 30.4 & 26.3 & 44.4 & 69.2 & 80. & 75. & $\overline{75 .}$ & 57.8 & 19.8 \\
\hline 9 & 0. & 0. & 50. & 34.6 & 28. & 18.2 & 62.5 & 72.7 & 33.2 & 25.4 \\
\hline 10 & 64.7 & 66.6 & 57.1 & 47.4 & 47.5 & 65.5 & - & - & 58.1 & 8.2 \\
\hline 11 & 100. & 0. & 50. & 100. & 0. & 100. & - & - & 56.3 & 44.9 \\
\hline 12 & 40. & 50. & 42.7 & 0. & 44.4 & - & - & - & 35.4 & 17.9 \\
\hline 13 & 95.6 . & 92. & 83.3 & $\overrightarrow{92.3}$ & 78.9 & - & - & - & 88.5 & 6.3 \\
\hline 14 & 0. & 0. & 33.3 & 88.8 & 80. & 50. & - & - & 42.1 & 34.8 \\
\hline Tot. & 647.6 & 622.5 & 794. & 839. & 844. & 850. & 584. & 432 & & \\
\hline $\begin{array}{l}\text { Obs. } \\
\text { Meal }\end{array}$ & n 49.8 & 44.4 & 56.7 & 59.9 & 60.3 & 70.8 & 64.9 & 54.0 & & \\
\hline $\begin{array}{l}\text { Cor. } \\
\text { Mea }\end{array}$ & n 49.8 & 51.9 & 56.7 & 59.9 & 60.3 & 70.8 & 64.9 & 72.0 & & \\
\hline ta & 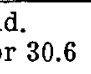 & 37.5 & 18.3 & 20.9 & 26.2 & 23.3 & 19.7 & 18.0 & & \\
\hline
\end{tabular}


From the results it would appear that sunlight has an influence upon adult emergence, which increases with the distance from the trunk. However, if we consider only the observed means, the data are not so conclusive. Yet it must be emphasized that the observed means were improperly based in part on certain values which are abnormally low or high. Accordingly, all data which fall outside the range included in twice the standard error, i.e., having a probability of less than 5 per cent have been left out for the calculation of the corrected mean. In Table 4 those abnormal values are under. scored.

\section{Location of larval population}

Another type of experiment was devised to determine the place on the tree where the larvae prefer to feed. The method consisted of dividing the area under the crown into 8 equal sections with reference to the cardinal points of the compass after which the cocoons were collected and counted by sections.

This sampling was planned upon the assumption that the larva of the spruce sawfly, after falling from the tree, does not crawl very far before spinning its cocoon. The data obtained support this assumption. Moreover, according to Gobeil (1935) 70 per cent of the sixth stage larvae do not go farther than one foot from the falling point, while only exceptional individuals crawl farther than 2.5 feet. It, therefore, seems quite probable that the cocoons found in each section were formed by the larvae that had fallen from points in the tree directly above.

The experiments were carried out on two dominant white spruce trees with well-developed crowns. Therefore, if any preference for feeding was shown by the larvae it was due not to the tree itself but to some other factor. The cocoons were collected within each triangle, of which the equilateral sides were 7 feet long, the third side 5.4 feet, and the area 17.4 square feet. A record of the cocoons was kept for each of the eight triangles around each tree and the percentages of the population corresponding to the north, east, south and west sides were then computed. The results are presented in Table 5 .

Table 5. Influence of sunlight upon Location of Larval Popdlation

\begin{tabular}{l|cc|cc|cc|cc}
\hline \hline Tree & \multicolumn{2}{|c|}{ North } & \multicolumn{2}{|c|}{ East } & \multicolumn{2}{|c|}{ South } & \multicolumn{2}{|c|}{ West } \\
\cline { 2 - 10 } No. & Population & $\%$ & Population & $\%$ & Population & $\%$ & Population & $\%$ \\
\hline 1 & 1,104 & 20.7 & 1,427 & 26.7 & 1,426 & 26.7 & 1,389 & 26.0 \\
2 & 803 & 17.1 & 1,248 & 26.2 & 1,633 & 34.3 & 1,069 & 22.4 \\
\hline Total & 1,917 & 18.9 & 2,675 & 26.4 & 3,059 & 30.2 & 2,456 & 24.3 \\
\hline
\end{tabular}

Cocoons were most abundant on the south side of the tree, whereas the east and west sides harbored approximately equal percentages of the population. On the other hand, the north side of the tree shows the lowest percentage. It is generally admitted that this side of a tree does not receive as much of the sun's rays as the others. It would, therefore, seem that the larvae prefer to feed on that section of the tree which receives more sunlight. 


\section{EFfect of HuMTDITY}

To determine accurately the relation between cocoon population and humidity of the ground cover and humus over such large plots as those we investigated would have involved the use of many expensive instruments. For this reason our classification of the various habitats according to the relative humidity was only general and based upon an ecological study of the plants which occurred in each sample plot. The moss Sphagnum for instance always occurs in very moist situations (Grout, 1924). The black spruce is also known to develop mostly in damp places. Taking such criteria into consideration the plots were classified in the following sequence: (1) mature black spruce, (2) young black spruce, (3) mixed spruce, (4) young and dense white spruce, (5) pasture stand of white spruce, (6) young and open white spruce. Percentages of emergence and mortality were computed for each plot and a mean calculated for each type of stand. The data obtained are presented in Table 6.

Table 6. adult Emergence and MortaltTy in Retation to HuMidity

\begin{tabular}{|c|c|c|c|c|c|c|}
\hline & Type of stand & $\begin{array}{l}\text { Sound } \\
\text { cocoons }\end{array}$ & $\begin{array}{c}\text { Emerged } \\
\text { cocoons }\end{array}$ & $\begin{array}{c}\text { Percentage } \\
\text { of emergence }\end{array}$ & $\begin{array}{c}\text { Dead } \\
\text { cocoons }\end{array}$ & $\begin{array}{l}\text { Percentage } \\
\text { of mortality }\end{array}$ \\
\hline $\begin{array}{l}\text { 1) } \\
\text { 2) } \\
\text { 3) } \\
\text { 4) } \\
\text { 5) } \\
\text { 6) }\end{array}$ & $\begin{array}{l}\text { Mature black spruce .... } \\
\text { Young black spruce ..... } \\
\text { Mixed spruce .......... } \\
\text { Young \& dense wh. sp. . . } \\
\text { Pasture stand of wh. sp. } \\
\text { Young \& open wh. sp. ... }\end{array}$ & $\begin{array}{r}12,428 \\
\\
5,693 \\
12,685 \\
8,636 \\
7,977 \\
. \quad 49,080\end{array}$ & $\begin{array}{r}29,622 \\
13,113 \\
15,624 \\
5,040 \\
13,110 \\
8,175\end{array}$ & $\left.\begin{array}{l}70.5 \\
71.3 \\
55.2 \\
37.0 \\
62.1 \\
14.3\end{array}\right\} \begin{array}{l}70.9 \\
57.2\end{array}$ & $\begin{array}{r}3,883 \\
4,480 \\
13,295 \\
37,067 \\
8,828 \\
1,194\end{array}$ & $\begin{array}{r}\left.\left.\begin{array}{r}8.5 \\
19.6 \\
32.0\end{array}\right\} \begin{array}{l}14 . \\
73.0 \\
29.5 \\
2.0\end{array}\right\} 34.8 \\
\end{array}$ \\
\hline
\end{tabular}

From these data it seems quite evident that the percentage of adult emergence is dependent largely upon the degree of humidity with the higher percentage occurring in the moister places. Also Balch (1939) noted that moist conditions and a warm spring favor a higher percentage of emergence. In our observations the emergence was at maximum with 70.9 per cent in the black spruce stands which are confined for the most part to swamps and undrained places (Morton 1917). The mixed white and black spruce habitat comes next with 55.2 per cent of adults issued. In the driest situation represented by the pure white spruce stands, which generally grow on well drained, moist and gravelly soil, the emergence was only 37.8 per cent.

If we now consider figures on mortality we see that it increases in drier habitats. In black spruce stands the mortality is 18 per cent lower than in the mixed spruce type. The percentage of mortality of the mixed type is also lower by 2.8 per cent than the white spruce type although the latter is already abnormally low at 34.8 per cent. This is due to the 2 per cent of mortality found for the open white spruce stand. Considering that collection was made before the new crop had been formed, the only explanation that could be given for this low percentage was that it might be due to the quality of the foliage eaten. Perhaps the larvae acquire more resistance in feeding on the young trees. 


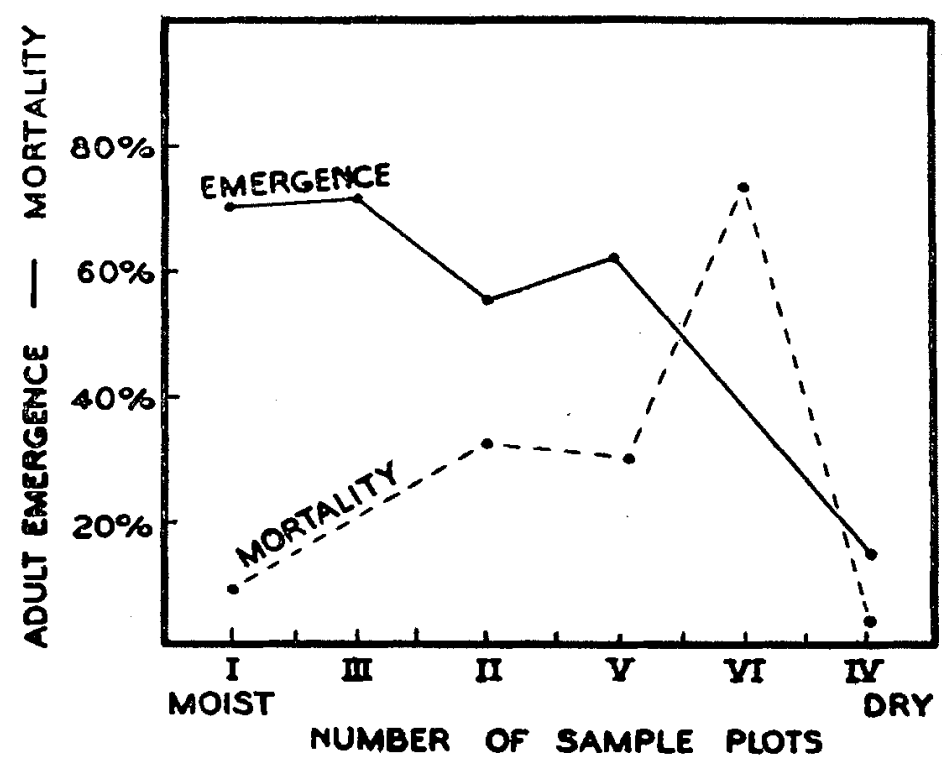

Fig. II. Influence of humidity upon emergence and mortality

The same data formed the basis for the preparation of the graph shown in Fig. II. The two curves illustrate directions which are very significant. As a whole, the percentages representing the emergence of the adult increase when those standing for mortality are decreasing.

\section{Influence of Smail Mammats}

Apparently many species of rodents prey upon the cocoons of Gilpinia hercyniae. The predominant predators are doubtlessly shrews, mice and squirrels. According to M. L. Prebble (letter of Feb. 1940), the shrews Blarina brevicauda and Sorex cinereus are the most important. Balch (1939) found that shrews, mice and squirrels do not apparently take more than one half of the cocoons. Our studies in 1938, 1939 and 1940 showed that 60.4 per cent of the 645,580 cocoons collected within the sample plots were chewed by rodents (Table 7). Although based on a large number of cocoons, this figure should not be considered as representative of the whole regions investigated. It applies especially to heavily infested stands such as the ones studied.

From the data given in Table 7 , it is clear that the small mammals are valuable agents in the control of the spruce sawfly. As many as 60.4 per cent of the larvae that succeeded in spinning cocoons were destroyed by these animals. However, the percentage of insects actually eaten is a little lower since we are informed that mice open dead and parasitized cocoons also. The survival, which includes the sound and emerged cocoons, represents only 27.9 per cent of the total population. 
Tabre 7. Classtrication of the Cocoons Found in the Ptots

\begin{tabular}{rr|r|r|r|r|r}
\hline $\begin{array}{c}\text { Sample Plot } \\
\text { No. }\end{array}$ & Sound & Dead & Chewed & Emerged & Parasitized & Total \\
\hline I & 12,428 & 3,883 & 91,043 & 29,622 & 1,056 & 138,032 \\
II & 5,693 & 4,480 & 109,050 & 13,113 & 200 & 132,536 \\
III & 49,080 & 1,194 & 55,071 & 8,175 & 336 & 113,856 \\
IV & 7,977 & 8,828 & 49,535 & 13,110 & 1,530 & 80,980 \\
V & 8,636 & 37,067 & 37,809 & 5,040 & 2,980 & 91,532 \\
VI & 12,685 & 13,295 & 49,181 & 15,624 & 859 & 91,644 \\
\hline Total & 96,499 & 68,747 & 391,689 & 84,684 & 6,961 & 648,580 \\
\hline Percentage & 14.8 & 10.6 & 60.4 & 13.1 & 1.1 & 100. \\
\hline
\end{tabular}

The proportion of chewed cocoons may be subdivided into two parts according to the place where they were found. A small percentage, i.e., 2.9 per cent as presented in Table 8, was located in the shrews' runways while the others were scattered all over the plot. In general, animals are said to store food either for their subsistance during the unfavourable period of the winter or as a reserve for their progeny. In the present instance the first hypothesis is improbable because the shrews that we are dealing with are active throughout the year and at all hours of the day and night (Hamilton 1940). Furthermore, the amount of food stored in the runways would not have been sufficient for those species of shrews, particularly for Sorex cinereus which eats 3.3 times its own weight every twenty-four hours. On that basis, a shrew weighing 3.6 grams would eat 11.7 grams of food per day or approximately 1,000 grams during the three winter months. Considering that 50 per cent of the food eaten by shrews is insects (Hamilton 1941) and that 100 cocoons weigh 6.2 grams, it would have taken 8,500 cocoons to feed one shrew during the winter. This is far from the average of 98 cocoons found per hoard.

Table 8. Classification of the Chewed Cocoons found in the Plots

\begin{tabular}{|c|c|c|c|c|c|c|}
\hline \multirow{3}{*}{$\begin{array}{l}\text { Plot } \\
\text { No. }\end{array}$} & \multicolumn{5}{|c|}{ Chewed Cocoons } & \multirow{3}{*}{$\begin{array}{l}\text { Number } \\
\text { of hoards }\end{array}$} \\
\hline & \multirow{2}{*}{ Total Number } & \multicolumn{2}{|c|}{ In runways } & \multicolumn{2}{|c|}{ Outside of runways } & \\
\hline & & Number & $\%$ & Number & $\%$ & \\
\hline I & 49,535 & 2,040 & 4.1 & 47,495 & 75.9 & 18 \\
\hline II & 37,809 & 518 & 1.4 & 37,291 & 98.6 & 8 \\
\hline Total & 87,344 & 2,558 & 2.9 & 84,786 & 97.1 & 26 \\
\hline
\end{tabular}

It is also doubtful that these cocoons opened by shrews would have served for the feeding of the young because the first litter is probably not born in Quebec before the beginning of May, when food is usually abundant. The explanation given by W. S. Hamilton (letter March 5, 1941) is that the cocoons were taken into the runways merely to be eaten at the time. This is not what we usually have in mind when we speak of a cache of food. 
When examined, the contents of all hoards were found to be eaten with the exception of one, which remained uneaten probably because the owner lost trace of it or died.

\section{E. Influtance of Parasttes}

The only manner in which it was possible to check upon the percentage of parasitism in our study was by the small hole through which the adult parasite emerged from the cocoon. However, the cocoons bearing the characteristic hole were not the only ones to be parasitized since some of the parasites had not yet reached the adult stage when the cocoons were collected or had died before they matured. In that case it was impossible to detect their presence by the field methods employed.

The data in Table 7 show that 1.1 per cent of the 645,580 cocoons collected within the sample plots were classified as parasitized cocoons. This figure is probably too low as an actual percentage on account of the fact that no consideration was given to the cocoons accumulated before parasites entered the plots.

\section{Growth Reduction and Mortality}

The effect of defoliation on the growth of trees has been proven through both experiments and field observations. Craighead (1924) mentions that an experiment was performed by Hartig on spruce and pine in order to check experimentally the effect of defoliation. The results were that an important reduction in growth occurred in the same year that the foliage was removed. The study made by Craighead himself (1924) on the damage caused to balsam fir and spruce by the spruce budworm, (Cacoecia fumiferana Clem), is also good proof that defoliation has a deleterious effect upon the growth.

The effects of defoliation were also tested on tamarack, (Larix laricina Kock), by Graham (1931). He reports that the reduction in the increment is directly proportional to the amount of defoliation. A gradual reduction in increment follows a partial defoliation whereas a complete defoliation causes a larger increment during the first year, followed by a rapid decrease. Practically the same conclusions were reached by Evenden (1940) from his study of the effect of defoliation by the pine butterfly (Neophasia manapia Fel), upon ponderosa pine (Pinus ponderosa Dougl.). The detailed measurements and the analysis of the increment cores showed that a reduction in growth follows defoliation. In addition, the defoliation by the pine butterfly caused the death of 26 per cent of the matured trees.

The series of increment cores taken from the trees in all of our. sample plots furnished ample opportunity for checking whether any noticeable reduction in the growth of the trees has been effected by this insect. The annual rings were measured to the hundredth of an inch by means of a ruler and a lens. The measurements on the growth were taken for the 15 years prior to the year of study and a reading was taken for the increase in diameter made during the last $3,6,10$ and 15 years. The data obtained were used 
to compute the mean rate of growth for each plot and for each crown class separately, that is, for the dominants, the co-dominants and the intermediates. In the case of Plots I and II even the trees which were in the area encircling the plot were used in our calculations.

\section{Plot I. Mature black spruce}

It has been known for many years that the spruce trees suffered much damage along the Cascapedia River and along the upper waters which in clude Lake Ste. Anne. This was verified through the study of Plot I in which the annual rate of growth was found to have been reduced for the majority of the trees since 1930. The data have been plotted in a graph which is presented in Fig. III.

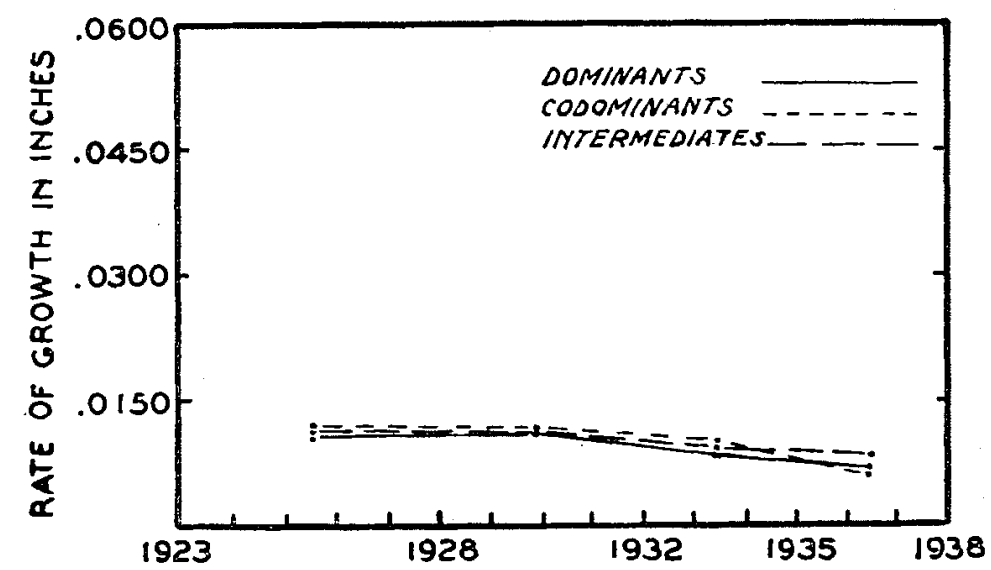

Fig. III. Rate of growth of the spruce in Plot I. (Black spruce stand)

It will be observed that the general direction of the curves changes in 1930 , which corresponds to the year in which the insect was found to have caused noticeable defoliation in the interior of the Gaspe Peninsula. The reduction in growth, however, is not as apparent as it is in the other plots because we are dealing with trees 120 years old yet averaging only 5.3 inches in diameter. Even so, a decrease in the rate of growth is observable. How ever, this damage cannot be attributed only to the spruce sawfly since the presence of a bark beetle, Dendroctonus piceaperda Hopk., was recorded in this sample plot. This beetle contributed at least partially to the damage caused to the trees and to the mortality which averaged 3.8 per cent.

\section{Plot II. Young black spruce stand}

The growth of the black spruce stands suffered more severely at Ruisseau Creux in the Matapedia Valley Region than at Lake Ste. Anne. This may be verified from Fig. IV. The decrease is quite evident in this case. If we consider the curves of the particular crown classes separately, we find that the co-dominant class is most affected. In fact the curve by which this class 
is represented drops down in 1931, while the other classes show an increase until 1934. This increase is comparable to that in observations mentioned previously herein by Graham (1931) on tamarack and Craighead (1924) on balsam fir.

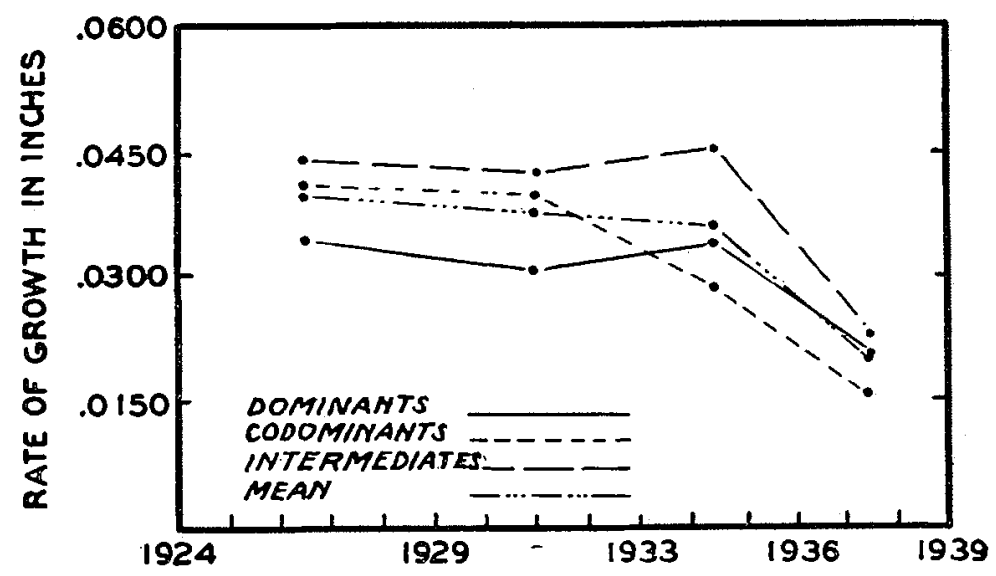

Fig. IV. Rate of growth of the spruce in Plot II. (Black spruce stand)

The curves representing the annual rate of growth for the dominants and intermediates show a reduction only in 1935 but the drop is much more important than that for the co-dominants.

Plot III. White spruce pasture stand

Growth studies in this sample plot were undertaken with a little hesitation because the trees were very young. Knowing that the annual growth in diameter is greater during the first years than when the tree becomes older, a decrease in the diameter growth might have been due to advancing age

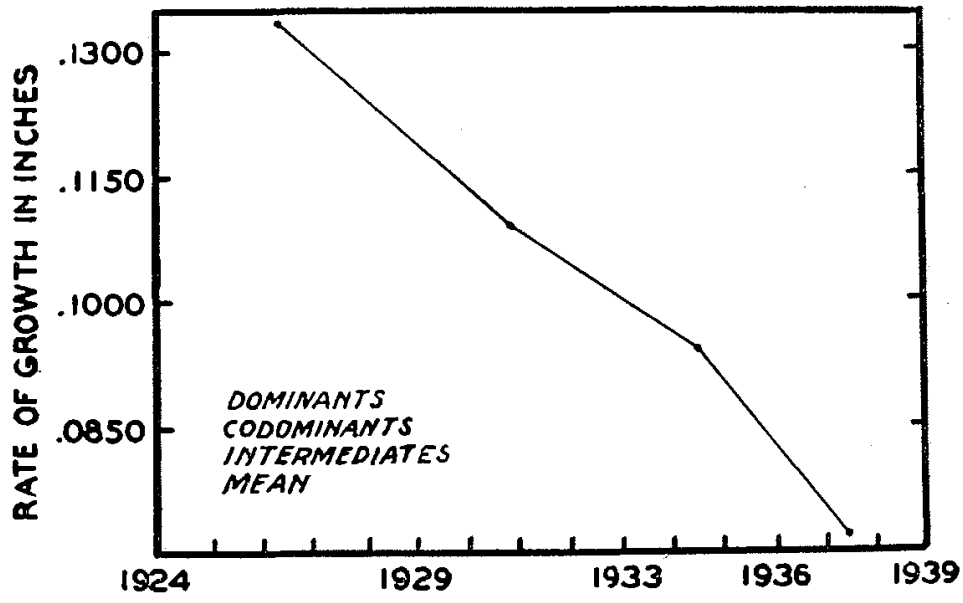

Fig. V. Rate of growth of the spruce in Plot III. (White spruce stand). 
rather than to feeding of the sawfly. Nevertheless, the computations were made.

Figure $\mathrm{V}$ shows a decrease in growth throughout the last 13 years. How, ever, it will be observed that the general direction of the curve changes slightly and that the slope is accentuated in 1935. This change is due to the interference of some external factor, probably the spruce sawfly. Yet the influence of this agent was not great enough to cause any mortality.

Plot IV. Young dense white spruce stand

The effect of defoliation upon white spruce is also illustrated by the data collected from the older spruce forest stand studied in plot IV. Figure VI, which shows these data graphically, indicated that the rate of growth was quite regular prior to 1932, and that the curve representing each of the different crown classes drops during the subsequent period down to 1940. In this case the dominant trees suffered the most evident damage. The codominant and the intermediate trees, although not greatly affected, likewise suffered a decline in their rate of growth. Despite the fact that the infestation was very heavy, no mortality has occurred to date.

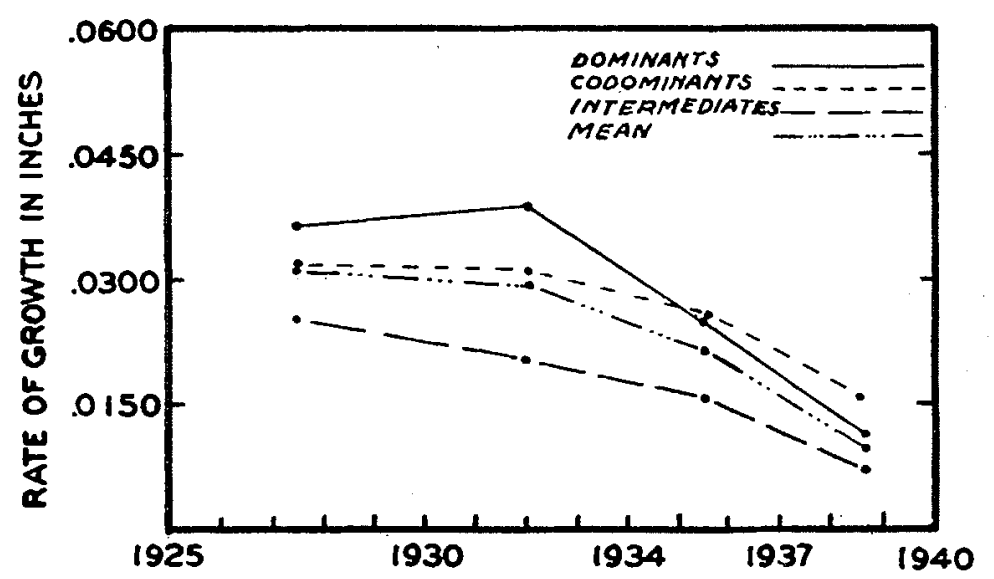

Fig. VI. Rate of growth of the spruce in Plot IV. (White spruce stand)

\section{Plot V. Young open white spruce stand}

This plot furnished another good example of the effect of defoliation upon white spruce. The comments made above for the trees of Plot IV might be repeated for Plot $\mathrm{V}$ so far as growth reduction is concerned. However, it will be observed further in Fig. VII, that the main slope of the curves occurs between 1932 and 1936. Thereafter the curves tend to take a rather horizontal direction. This probably indicates that the spruce sawflies were very abundant during that period and very rapidly completed the defoliation of the trees. Thus 3 or 7 years of attack was sufficient in the open stand (Plot V) to produce approximately the reduction in growth resulting during 7 or 8 years in the dense stand (Plot IV). Here again no evidence of mortality was observed. 


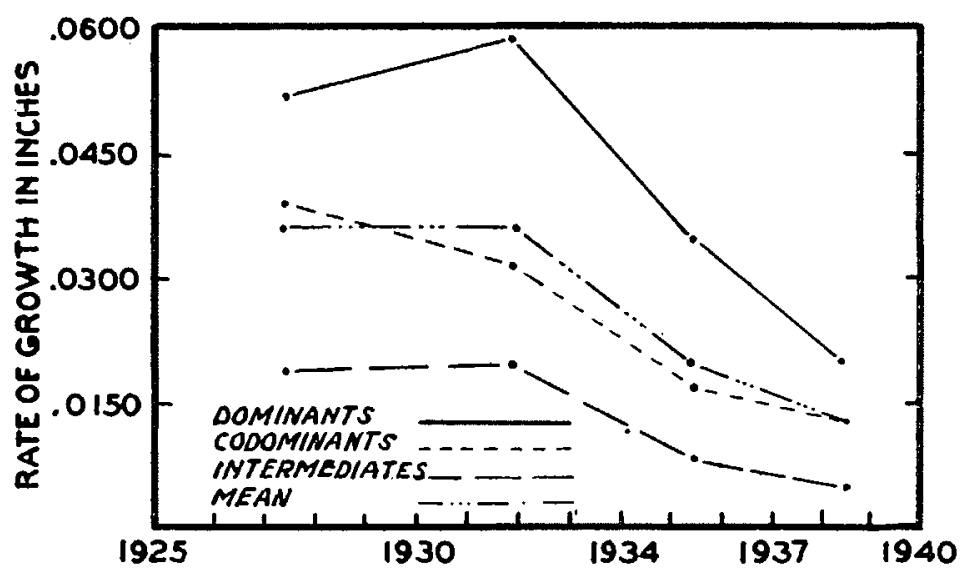

Fig. VII. Rate of growth of the spruce in Plot V. (White spruce stand)

\section{Plot VI. Mixed type}

The study of growth in the mixed forest stand investigated at Lake Ste. Anne gave different results from those obtained for the black spruce stand studied in the same locality. The reduction in growth is more striking than in Plot I, probably because the stand was composed of both black and white spruce, the growth of the latter being more affected by the insect. The curves given in Fig. VIII, show a normal increase in diameter from 1926 to 1931. But from the latter date until 1938 the curves illustrate a marked decrease which is most evident on the dominant trees. Moreover, 4 white and one black spruces out of a total of 28 were dead, giving a percentage of mortality of 17.9 . In Plot I only 3.8 per cent of the black spruce trees were dead.

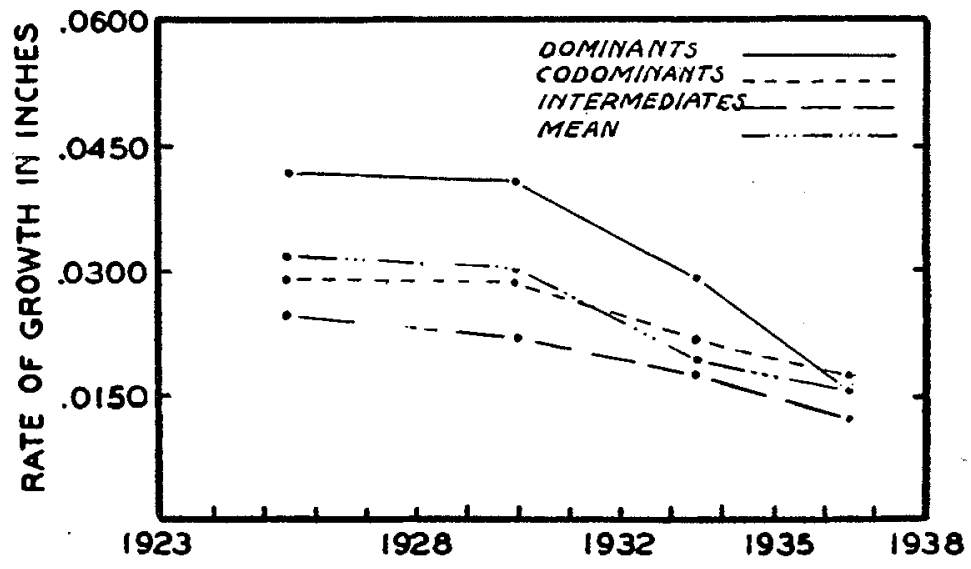

Fig. VIII. Rate of growth of the spruce in Plot VI. (Mixed stand) 
On the whole, a general reduction in the growth of the spruce trees probably due to the spruce sawfly infestation was found in all the sample plots studied and this decrease seems more important in the case of the dominant trees than for the other classes. The reduction was noticeable around 1930 in the Gaspe Region where many trees were actually killed. In the Matapedia Valley Region the decrease became apparent only in 1932.

\section{SumMary AND CONCLUSIONS}

Population studies of the spruce sawfly, (Gilpinia hercyniae Htg.), were performed in various types of stands found in the Gaspe Peninsula and Matapedia Valley regions of the Province of Quebec. The object of this work was to correlate the abundance of this insect with the ecological factors of the spruce habitat. The principal conclusions which were derived follow:

1. Emergence of the adult from the cocoon is affected by the thickness of the humus layer. Apparently a layer of humus of 4 to 6 inches deep would be ideal for maximum emergence. It is also generally true that the deeper the humus the more important is the control by the rodent predators upon the cocoons.

2. Sunlight favors the emergence of the adult from the cocoon. It also influences the larvae in that they prefer feeding in sunny places like the east, south and west sides of a tree rather than the north.

3. Humidity of the humus was shown to increase adult emergence and reduce mortality.

4. Mice, shrews and squirrels constitute very important natural agencies in the control of the spruce sawfly. In our studies 60.4 per cent of the 645,580 cocoons found within the limits of the plots were chewed by these predators.

5. To date the parasites have been a much less important control factor than the rodents.

6. As a result of the defoliation by the spruce sawfly, a marked decline in the rate of growth of the spruce has been noticed during the last decade.

Balch, R. E. 1939

Craighead, F. C. 1924

DeGryse, J. J. 1934

\section{BIBLIOGRAPHY}

The Outbreak of the European Spruce Sawfly in Canada and Some Important Features of its Bionomics. Jour. Econ. Ento., 32 (3) : 412-418.

Studies on the Spruce Budworm. Bull. 37. Dept. Agric., Dom. of Canada.

Quantitative Methods in the Study of Forest Insects. Scientific Agriculture, 14: 477-495. 
Evenden, J. C. Effects of defoliation by the Pine Butterfly upon Pon1940

Gobeil, A. R. 1935 derosa Pine. Jour. of Forestry, 38:949-956.

Studies of Diprion polytomum at Parke Reserve. (unpublished). Ann. Rept. Div. Forest Insects, Ent. Br. Dept. Agr. Can.

Graham, S. A. The Larch Sawfly as an Indicator of Mouse Abund1929 ance. Jour. Mammalogy, Vol. 10:3:189-196.

1931

The Effect of Defoliation on Tamarack. Jour. of For. estry, 29 (2):199.206.

Grout, A. J. Mosses with a Hand-Lens. 3rd Edition. 1924

Hamilton, W. J. Jr. The Biology of the Smoky Shrew (Sorex fumeus fu1940 meus Miller). Zoological, XXV:473-492.

1941

The food of Small Forest Mammals in Eastern United States. Jour. Mammalogy, 22:3:250-263.

King, $\mathrm{M}$. 1939

Population Studies of Soil Insects. Ecol. Mono., 9: 270.286.

Morton, B. R. 1917

Native Trees of Canada. Bull. 61, Forest Service, Dept. of the Interior, Canada. 